\title{
Can renewable energy be used as an effective tool in the decarbonization of the Mediterranean region: fresh evidence under cross-sectional dependence
}

\author{
Zubeyde Senturk Ulucak $^{1}$ (D) Ali Gokhan Yucel $^{2}$ (D) \\ Received: 29 December 2020 / Accepted: 6 May 2021 / Published online: 17 May 2021 \\ (C) The Author(s), under exclusive licence to Springer-Verlag GmbH Germany, part of Springer Nature 2021
}

\begin{abstract}
Many studies in the literature confirm the validity of the technique effect, which improves the quality of the environment by investigating whether an inverted $U$-shaped relationship exists between environmental pollution and economic growth. Ignoring the role of the technological obsolescence effect, which may also exert influence on an economy, these studies reach an optimistic conclusion for growth policies. By controlling renewable energy, this study examines the existence of the obsolescence effect by constructing an N-shaped relationship between economic growth and environmental degradation for the most vulnerable countries in the Mediterranean region to climate change. We conducted a battery of cross-sectional dependence tests, secondgeneration panel unit root, and cointegration tests in 17 selected Mediterranean countries covering 1990-2017. The results provide evidence of an $\mathrm{N}$-shaped relationship between economic growth and environmental degradation. The study provides important policy recommendations and discusses how renewable energy can be deployed to reduce $\mathrm{CO}_{2}$ emissions.
\end{abstract}

Keywords Carbon emissions $\cdot$ Renewable energy $\cdot$ Cross-sectional dependence $\cdot$ Cointegration $\cdot$ Panel data $\cdot$ Mediterranean countries

JEL classification $\mathrm{C} 33 \cdot \mathrm{K} 32 \cdot \mathrm{O} 13 \cdot \mathrm{O} 44$

\section{Introduction}

The Mediterranean region borders more than twenty sovereign countries with similar climate characteristics around the Mediterranean Sea. The region is one of the most rapidly growing regions in the world in terms of energy demand. Parallel to rapid energy demand, the region is at the center of climate discussions. In their pioneering research, Guiot and Cramer (2016) projected that at or above $2^{\circ} \mathrm{C}$ temperature rise would lead to changes in Mediterranean ecosystems that

Responsible Editor: Ilhan Ozturk

Ali Gokhan Yucel agyucel@erciyes.edu.tr

Zubeyde Senturk Ulucak zsulucak@erciyes.edu.tr

1 Department of Public Finance, Erciyes University, Kayseri, Turkey

2 Department of Economics, Erciyes University, Kayseri, Turkey are unmatched in the past 10,000 years. The authors warned that if greenhouse gases (GHG) are not curbed, the forests of southern Spain and North Africa will probably turn into a desert by the end of the century. In another seminal study, Cook et al. (2016) argued that the climate variability in the Mediterranean region is still poorly understood, and it is at an alarming level due to rising drought variability through projections from climate models. Due to the surrounding desert impact caused by the South Asian summer monsoon, the region is highly vulnerable and under the pressure of climate change (Kim et al. 2019). The climate variability is such that the highest temperatures for the summer and heat waves and irregularity in rainfall have been noted down in recent times (Christensen et al. 2013; Frölicher and Laufkötter 2018; Mathbout et al. 2020; Nashwan et al. 2020). So, the current situation of the region calls for urgent action plans to cushion it from the effects of climate change and to contribute to pursuing efforts to limit global temperature rise to $1.5^{\circ} \mathrm{C}$ as was projected and dramatically highlighted by the Intergovernmental Panel on Climate Change (IPCC) reports. 
Following scientific climate projections, the IPCC and many international attempts heavily underline that the most important action is to mitigate carbon dioxide $\left(\mathrm{CO}_{2}\right)$ emissions below its preindustrial level since carbon emission accounts for the largest share in forming the greenhouse effect over the atmosphere, among other greenhouse gases such as methane, nitrous oxide, and chlorofluorocarbon (IPCC 2014, 2018). Besides, countries should arrive at a consensus to address this threat collaboratively since no country can avert it alone (Ulucak et al. 2019; Puaschunder 2020). However, taking action collaboratively with the leading contributors to global warming, which is also the reason for the instability of climatic conditions in the region, deters countries due to the economic cost of emission cuts, as countries do not consent to be equally responsible for emissions (Najam et al. 2003). This is one of the most important reasons why the Kyoto Protocol failed in the implementation (Rosen 2015).

Although countries object to being equally responsible for global warming and climate change, research indicates that countries should use the same transitional path in terms of carbon emissions by converging to similar equilibrium points, a necessity in the face of looming environmental catastrophe (Aldy 2006; Westerlund and Basher 2008; Herrerias 2013; Bilgili and Ulucak 2018; Bilgili et al. 2019; Ulucak et al. 2020a). On the other hand, one of the most important inferences from econometric estimations, on that empirically supports the need for common action in mitigating emissions into the atmosphere, is obtained by an inverted U-shaped relationship between economic growth (or income level) and environmental degradation (Stern 2017). The representation of an inverted Ushaped relationship, by adopting the seminal approach of Kuznets (1955), was later explained by Grossman and Krueger $(1991,1995)$ through three effects for the incomeenvironment nexus, thus called the environmental Kuznets curve (EKC) hypothesis which later became one of the most famous approaches to analyze environmental consequences of economic, social, cultural, and technological factors (Dinda 2004; Pincheira and Zuniga 2020; Erdoğan et al. 2020).

The EKC hypothesis is based on three channels to explain how countries may decrease $\mathrm{CO}_{2}$ emissions as their gross domestic product rises (Grossman and Krueger 1995; Panayotou 1995). The first channel is the scale effect based on the fact that emissions would increase as the quantity of production increases in an economy at its first stage of development. However, the service sector that causes less emission than the industrial sector expands in such an economy as it develops with increasing income level, and thus, the structure of the economy turns to be a service sector-intensive one. This transformation is named the composition effect that is the second channel. Further, countries can allocate more budget to promote technological progress as they develop, and technological improvement allows them to produce goods and services through cleaner strategies that help the mitigation of
$\mathrm{CO}_{2}$ emissions. This mechanism is the third channel expected to decrease emissions in an economy, called the technique effect. Considering these effects, the EKC hypothesis postulates that $\mathrm{CO}_{2}$ emissions will eventually decrease in an economy as the income level rise through composition and technique effects (Panayotou 1993, 1995). On the other hand, another effect is also probable at the end of the process driven by an inverted U-shaped relationship of the scale, composition, and technique effects. It is called the technological obsolescence effect that changes the inverted U-shaped into an $\mathrm{N}$ shaped one since it is attributed to depreciation and obsolescence in capital and technology, which lead to an increase in pollution (Sinha et al. 2017).

Considering the climate conditions in the Mediterranean region and the empirical implications of the ECK concept, this study aims to investigate how $\mathrm{CO}_{2}$ emissions respond to income rise in Mediterranean countries by controlling renewable energy since renewable energy deployment is the optimal solution to decrease carbon emissions and to tackle climate change. As well as checking the validity of scale, composition, and technique effects, this study will also empirically reveal a possible N-shaped relationship through technological obsolescence effect between income and environmental pollution and whether a common policy is required to moderate the adverse effects of irregular climate patterns. To this end, the study performs second-generation panel data techniques, which eliminate estimation inconsistency or bias stemming from cross-correlations among residuals. Before performing econometric analyses, the study presents a brief literature survey to show how available studies in the related literature examined the EKC concept and what findings were obtained through various dataset, variables, and country-country groups.

We used annual time series data for 17 Mediterranean countries, covering the period of 1990-2017. More specifically, we employed a battery of cross-sectional dependence and first- and second-generation panel unit root tests with and without structural breaks. Overall, the results are expected to provide valuable insights for both researchers and policymakers.

The rest of the paper is organized as follows. The following section provides literature review. The third section introduces the data and econometric methodology and presents the empirical findings. The last section concludes the study with policy recommendations.

\section{Literature review}

With the global awareness of environmental issues, researchers have started to study the EKC hypothesis. Even though research on the EKC hypothesis has grown dramatically over the past decades, there has not been a consensus in the literature on whether the EKC hypothesis holds (Sarkodie 
and Ozturk 2020). The reasons for the contradicting results lie in the choice of sample, country-specific characteristics, variable selection, time period, and/or econometric methodology. ${ }^{1}$

Basic investigation of the environmental Kuznets curve hypothesis requires two main indicators that are mainly based on alternative income and environmental degradation measurements which are theoretically probable outcomes of increasing income level on environmental pollution (Panayotou 1993, 1995). Then, the estimation model based on an inverted U-shaped relationship is generally constructed as a quadratic equation (Sinha and Shahbaz 2018; Destek et al. 2018; Yilanci and Ozgur 2019; Sarkodie and Ozturk 2020), although some arguments extend this specification with the possibility of $\mathrm{N}$-shaped relationship between income and environmental degradation in a cubic equation by considering depreciation in the capital and obsolete technology (Shafik 1994; Jiang et al. 2019; Barış-Tüzemen et al. 2020; Usama et al. 2020). A cubic N-shaped relationship covers the scale, composition, and technique effects and indicates that pollution level falls until a threshold is reached as in the inverted Ushaped relationship, but it underlines that a reincrease in environmental deterioration is probable unless technological progress does not sufficiently mitigate degradation. Therefore, the current literature underscores that countries should make constant improvements in technological progress, especially in energy-generating systems, to keep the situation pictured in the EKC relationship (Bhattacharya et al. 2017; Yao et al. 2019; Erdogan et al. 2020). In order to alleviate the deleterious effects of income rise on environmental pollution, current literature gives emphasis to renewable energy and widely adopts it as a control variable to analyze the existence of the EKC relationship.

Usama et al. (2020) examined the validity of the EKC hypothesis in a quadratic function of income and found an inverted U-shaped relationship by applying the ARDL approach on yearly data of Ethiopia, covering the period 1971-2015. The authors found that both renewable and nonrenewable energy decreases $\mathrm{CO}_{2}$ emissions.

Erdogan et al. (2020) conducted first- and second-generation panel cointegration estimators and verified the quadratic form of the EKC hypothesis through FMOLS and DOLS estimators for OECD countries. The authors emphasized the crucial role of renewable energy in mitigating $\mathrm{CO}_{2}$ emissions.

Akram et al. (2020) examined 66 countries by constructing a basic EKC model in which renewable energy is incorporated through panel ordinary least squares and panel quantile regression methods. They highlighted that renewable energy and energy efficiency contribute to obtaining the desired relationship for the EKC, although findings vary across quantiles,

\footnotetext{
${ }^{1}$ The interested reader may refer to Öztürk and Özcan (2019) for an excellent discussion on the EKC hypothesis.
}

e.g., at upper quantiles or lower quantiles for income levels of sample countries.

Balsalobre-lorente et al. (2018) tested a cubic form of the EKC concept for five selected European countries by performing a panel fixed effect estimator and obtained statistically significant outputs in favor of N-shaped relationship between $\mathrm{CO}_{2}$ emissions and income. Further, they also endorsed the reducing effect of renewable energy on environmental pollution, which improves the quality of the environment.

By carrying out the ARDL approach on annual data of China, Chen et al. (2019) found a monotonical relationship between income and $\mathrm{CO}_{2}$ emissions, which is incompatible with the relationship envisioned by the EKC concept. However, they revealed that this relationship turns to an inverted U-shaped if renewable energy is included as a control variable in the estimation, one of the major arguments that renewable energy takes on vital importance to drive the desired consequences of income rise.

Sharif et al. (2019) focused on the role of renewable and nonrenewable energy in shaping the EKC curve for 74 countries by using panel FMOLS estimator, and they validated the existence of the EKC hypothesis. They also discoursed more on the prime importance of green energy in decreasing environmental deterioration.

By putting forward the influence of neighboring in environmental pollution through spatial relationship, BaladoNaves et al. (2018) examined the quadratic form of the EKC hypothesis for 173 countries over the 1990-2017 period and documented affirmative findings for the hypothesis. Their results also highlighted the prominence of renewable energy to establish a sustainable environment and reduce global warming and climate change.

Sinha et al. (2017) built an N-shaped equation of the EKC model for N-11 countries and confirmed the technical obsolescence effect that formed a second threshold for income level, a stage where current technical endowment becomes obsolete, by using the panel GMM method.

Applying panel least squares estimator, Alvarez-Herranz et al. (2017) obtained results that validate N-shaped relationship in 17 OECD countries for the period 1990-2012. By performing ARDL bound testing approach for Pakistan, Danish et al. (2017) focused on the role of renewable energy in shaping the relationship between income and environmental pollution. The authors found that renewable energy contributes to decreasing $\mathrm{CO}_{2}$ emissions.

In a similar study, Magazzino (2017) investigated the relationship between renewable energy consumption and economic growth for Italy covering 1970-2017. An important finding of the study is that renewable energy consumption slows Italy's economic growth. The author explained the negative impact of renewable energy on economic growth with the transformation of production from energy-intensive sectors to less energy-intensive sectors. 
Bringing the role of renewable energy to the fore, some studies confirmed the EKC relationship in the quadratic form (e.g., Bölük and Mert 2015; Baek 2016; Sugiawan and Managi 2016; Bekhet and Othman 2018; Dong et al. 2018; Balado-Naves et al. 2018; Sharif et al. 2019; Pao and Chen 2019; Baležentis et al. 2019), while others did not find evidence in favor of this concept (e.g., Jebli and Youssef 2015; Zoundi 2017; Liu et al. 2017; Inglesi-Lotz and Dogan 2018; Zambrano-Monserrate et al. 2018; Chen et al. 2019). In order to take the technological obsolescence effect verified by Nshaped relationship into account, very few studies constructed the EKC model in the cubic form (López-Menéndez et al. 2014; Menegaki and Tsagarakis 2015; Alvarez-Herranz et al. 2017; Sinha et al. 2017; Balsalobre-lorente et al. 2018).

Specifically, there are very few studies investigating the EKC hypothesis in Mediterranean countries. Of them, Gürlük (2009) estimated a quadratic form of the hypothesis by focusing on the role of human development. The study used time series estimation methods and found mixed results for analyzed countries. Using the ARDL bound testing procedures, Zafeiriou and Azam (2017) examined the validity of the EKC hypothesis in the quadratic form for France, Portugal, and Spain. The authors concluded that the EKC relationship is valid for those Mediterranean countries in the long run.

Vehmas et al. (2007) examined the EKC relationship for aggregated material flows of EU countries through linking analysis and underlined France, Greece, Portugal, and Spain as Mediterranean countries among the EU countries. Their results did not provide any findings that indicate an inverted U-shaped relationship for those countries.

Finally, Alola et al. (2019) investigated 16 coastline Mediterranean countries and provided strong evidence that renewable energy significantly reduces $\mathrm{CO}_{2}$ emissions by carrying out panel GMM and panel ARDL estimators.

Considering the critical situation of the region, one can easily realize the need for efficient policy implications based on empirical investigations. However, there is a gap in the literature in that Mediterranean countries have not been sufficiently studied yet. Although there are studies in the literature that mostly focused on the quadratic form of the EKC relationship, very few tested the cubic form, the N-shaped relationship for different countries by considering the prominent role of renewable energy. Furthermore, no study considering the cubic function is available for Mediterranean countries in the literature. Therefore, this study is expected to fill this gap.

\section{Data, methodology, and findings}

The vast majority of the studies in the literature employ a quadratic function (Shahbaz et al. 2012; Bilgili et al. 2016; Cetin et al. 2018; Mahmood et al. 2019; Yao et al. 2019;
Köksal et al. 2020; Hassan et al. 2021) to test the existence of EKC hypothesis as given in Eq. (1).

$E=f\left(Y, Y^{2}, Z\right)$

where $E$ represents environmental degradation ${ }^{2}$ measured by various indicators, $Y$ represents income, $Y^{2}$ represents income squared, and $Z$ represents other variables that influence environmental degradation. However, we extended Eq. (1) by adding the cubic value of income as follows:

$\mathrm{CO}_{2}=f\left(Y, Y^{2}, Y^{3}, R E\right)$

where $\mathrm{CO}_{2}, Y, Y^{2}, Y^{3}$, and $R E$ denote carbon dioxide emissions, income and its squared and cubed terms, and renewable energy consumption, respectively.

In the next step, we transform all the variables into their natural logarithms to reduce variability and interpret the coefficients as elasticities. To remove the effects of population size on the variables and avoid any potential heteroskedasticity, we divided each variable by population to obtain per capita forms. Therefore, the estimation model is stated as follows:

$$
\begin{aligned}
\operatorname{lnCO}_{2_{i t}}= & \delta_{0}+\delta_{1 i} \ln G D P_{i t}+\delta_{2 i} \ln G D P_{i t}^{2}+\delta_{3 i} \ln G D P_{\widehat{i t}}^{3} \\
& +\delta_{4 i} \ln R E C_{i t}+\varepsilon_{i t}
\end{aligned}
$$

where $i=1,2, \ldots N$ represents cross sections forming the panel, and $t$ indicates time period; $\delta_{0} \ldots \delta_{4}$ are the unknown parameters to be estimated; and lastly, $\varepsilon$ is the idiosyncratic error term. Equation (3) provides several forms of the relationship between economic growth and environmental relationship depending on the sign of $\delta$, which are summarized as below:

(i) $\delta_{1}=\delta_{2}=\delta_{3}=0$ refers that carbon emissions are not influenced by income,

(ii) $\delta_{1}<0$ and $\delta_{2}=\delta_{3}=0$ refer to monotonically decreasing linear relationship in that carbon emissions decrease along with income increases,

(iii) $\delta_{1}>0$ and $\delta_{2}=\delta_{3}=0$ remark a monotonically increasing linear relationship in that carbon emissions increase along with income increases,

(iv) $\delta_{1}<0$ and $\delta_{2}>0$, and $\delta_{3}=0$ express a U-shaped relationship between carbon emissions and income, meaning that carbon emissions decrease up to a certain point as income increases; after that, it increases.

(v) $\delta_{1}>0$ and $\delta_{2}<0$, and $\delta_{3}=0$ indicate an inverted U-shaped EKC relationship implying that carbon emissions

\footnotetext{
${ }^{2}$ In the literature, several variables are proxied for environmental degradation. However, carbon dioxide emissions are the primary driver of climate change. Of the total greenhouse gases, carbon dioxide emissions account for about $76 \%$. Large amount of carbon emissions come primarily from burning fossil fuels such as coal, petroleum, and natural gas.
} 
increase up to a certain point as income increases; after that, it decreases,

(vi) $\delta_{1}>0$ and $\delta_{2}<0$, and $\delta_{3}>0$ reveal a cubic polynomial function with an $\mathrm{N}$-shaped relationship between carbon emissions and income. In this type of relationship, as income increases, carbon emissions initially increase, then decrease, and start to increase again.

(vii) $\delta_{1}<0$ and $\delta_{2}>0$ and $\delta_{3}<0$ specify a cubic polynomial function with an inverted $\mathrm{N}$-shaped relationship between carbon emissions and income.

To explore the relationship between environmental degradation, economic development, and renewable energy, we use annual data of 17 Mediterranean countries (Spain, France, Italy, Slovenia, Croatia, Bosnia and Herzegovina, Albania, Greece, Turkey, Lebanon, Israel, Egypt, Libya, Tunisia, Algeria, Morocco, Cyprus). To form a balanced panel, we restricted the time period from 1990 to 2017 . We excluded 4 Mediterranean countries, namely Montenegro, Malta, Monaco, and Syria, due to data unavailability. As the data frequency is annual, we do not deal with seasonality issues. The definition of the variables and data sources is tabulated in Table 1.

The descriptive statistics of the variables in natural logarithmic forms are presented in Table 2. GDP has the highest mean, while $\mathrm{CO}_{2}$ has the lowest one. Median statistics present similar results to the mean. Renewable energy consumption has the highest standard deviation; carbon emissions have the lowest standard deviation. All the series are negatively skewed and are right-tailed. The Jarque-Bera statistic shows that the null hypothesis of normality is strongly rejected for all the variables meaning that none of the series have a normal distribution.

\section{Cross-sectional dependence}

We start our analysis by checking the cross-sectional dependence (CD) among the variables as it is one of the most important diagnostics that one should examine when performing nonstationary panel analysis. This importance can be explained by renowned econometrician Hsiao's (2014) argument that not considering cross-sectional dependence in
Table 2 Descriptive statistics

\begin{tabular}{llll}
\hline & $\mathrm{CO}_{2}$ & GDP & REC \\
\hline Mean & 1.392854 & 9.090067 & 2.066321 \\
Median & 1.512114 & 9.060571 & 2.210138 \\
Maximum & 2.290190 & 10.66931 & 4.024518 \\
Minimum & -0.712605 & 6.553185 & -2.830918 \\
Std. dev. & 0.668649 & 1.052301 & 1.172674 \\
Skewness & -0.720249 & -0.098653 & -1.436304 \\
Kurtosis & 2.674938 & 1.652329 & 5.545982 \\
Jarque-Bera & 37.61709 & 32.00127 & 254.1598 \\
Probability & 0.000000 & 0.000000 & 0.000000 \\
\hline
\end{tabular}

Source: authors' own calculation

estimations could have significant consequences leading to efficiency loss in estimators and biased test statistics.

Cross-sectional dependence can arise due to various reasons, such as spatial/spillover effects or unobserved common factors. To test CD, we employed a variety of tests, namely the Lagrange multiplier test of Breusch and Pagan (1980, hereinafter LM), modified LM (hereinafter $\mathrm{CD}_{\mathrm{LM}}$ ), and cross-sectional dependence tests of Pesaran (2007, CD hereinafter) and also bias adjusted LM test of Pesaran et al. (2008, hereinafter $\mathrm{LM}_{\text {adj }}$ ).

The results of the cross-sectional dependency are given in Table 3. The null hypothesis of no cross-sectional dependency for all the series is overwhelmingly rejected at the $1 \%$ significance level. The economic interpretation of this result is that a given shock in any of the series in any of the countries will affect the same variable in other countries forming the panel. This result is fully in line with our expectations as these countries are economically and geographically dependent on each other.

Two important conclusions can be drawn from CD test findings. Firstly, our result supports the view of Carrion-iSilvestre et al. (2005) that the assumption of cross-sectional independence is hardly found in practice, especially in a globalized world where the shocks easily and rapidly overpass the borders of the countries. Secondly and more importantly, subsequent panel tests should account for cross-sectional dependence; otherwise, if left untreated, the results would be biased and inconsistent.
Table 1 Description of the variables

\begin{tabular}{|c|c|c|c|}
\hline Variable & Symbol & Unit of measurement & Source \\
\hline Carbon emissions & $\mathrm{CO}_{2}$ & Metric tons per capita & $\begin{array}{l}\text { BP Statistical Review of World } \\
\text { Energy }\end{array}$ \\
\hline Economic growth & GDP & $\begin{array}{l}\text { GDP per capita in constant } 2010 \\
\text { US\$ }\end{array}$ & $\begin{array}{l}\text { World Development Indicators, } \\
\text { WB }\end{array}$ \\
\hline $\begin{array}{l}\text { Renewable energy } \\
\text { consumption }\end{array}$ & REC & Per capita energy consumption & $\begin{array}{l}\text { International Energy Agency } \\
\text { (IEA) }\end{array}$ \\
\hline
\end{tabular}


Table 3 Cross-sectional dependency results

\begin{tabular}{lllll}
\hline & $\mathrm{LM}$ & $\mathrm{CD}_{\mathrm{LM}}$ & $\mathrm{CD}$ & $\mathrm{LM}_{\text {adj }}$ \\
\hline $\ln \mathrm{CO}_{2}$ & $247.14^{* * * *}(0.00)$ & $5.57^{* * *}(0.00)$ & $2.43^{* * * *}(0.00)$ & $26.13^{* * *}(0.00)$ \\
$\ln G D P$ & $272.15^{* * * *}(0.00)$ & $11.16^{* * *}(0.00)$ & $4.55^{* * * *}(0.00)$ & $33.15^{* * * *}(0.00)$ \\
$\ln R E C$ & $312.23^{* * * *}(0.00)$ & $3.25^{* * *}(0.00)$ & $-3.43^{* * *}(0.00)$ & $11.26^{* * *}(0.00)$ \\
\hline
\end{tabular}

Maximum number of lags is set to 2, and optimal lag length is chosen based on the Schwarz information criterion.

${ }^{* * * *}$ Significance at the $1 \%$ level. Values given in parentheses denote prob values

\section{Panel unit root tests}

As the findings imply cross-sectional dependence among the variables, first-generation panel unit root test results could be biased. Therefore, in the second stage of our analysis, we performed unit root tests of Pesaran (2007; CADF hereafter) and Hadri and Kurozumi (2012; HK hereafter), both of which are second-generation panel unit root tests. To briefly review these tests, cross-sectionally augmented ADF (CADF) test is based on ADF regressions augmented with the cross section averages. Pesaran also calculates the simple averages of CADF statistics referred to as the cross-sectionally augmented IPS (CIPS) test. While the CADF statistics give individual results, CIPS statistic gives the panel results. CADF and CIPS tests of Pesaran (2007) are two of the most popular second-generation test in the literature (Westerlund and Hosseinkouchack 2016). HK test, one of the many theoretical extensions of CADF test, suggests a null hypothesis of stationarity in heterogeneous panel data with cross-sectional dependence in the form of a common factor (Yucel 2020).

The results of CIPS and HK test are presented in Table 4. The null hypothesis of the unit root cannot be rejected in CIPS test, while it is strongly rejected in $\mathrm{HK}$ test, the null hypothesis of which is stationarity.

Having concluded that all the variables are stationary at their differences, we apply the Durbin-Hausman cointegration test developed by Westerlund (2008) to observe the existence of long-run equilibrium. This test has several advantages over other panel cointegration tests (Ulucak et al. 2020b): (i) it accounts for cross-sectional dependence by applying the principal components method to the residuals; (ii) it has a standard normal distribution meaning that it could be applied with a large number of explanatory variables; (iii) the regressor need not be nonstationary as opposed to many cointegration tests. Two types of estimators are derived based on Durbin-Hausman principle. A common value for the autoregressive parameter is assumed in $D H_{\mathrm{p}}$ statistic, while autoregressive parameters are assumed to be heterogeneous in $D H_{\mathrm{g}}$ statistic.

The results presented in Table 5 show that the null hypothesis of no cointegration is strongly rejected for both $D H_{g}$ and $\mathrm{DH}_{p}$ tests. This finding suggests that there is a long-run cointegration relationship among carbon emissions, income, and renewable energy consumption in the countries forming the panel.

In line with the Durbin-Hausman cointegration test results, we, in the last step of the analysis, proceed with the estimation of the long-run coefficients. In accordance with the results of $\mathrm{CD}$ tests, we performed continuously updated and biascorrected (CupBC) and continuously updated and fully modified (CupFM) estimators developed by Bai et al. (2009) to obtain long-term cointegration estimators. This selection was motivated by three remarkable features of these estimators: (i) these estimators control for the correlation among

Table 4 Second-generation panel unit root test results

\begin{tabular}{|c|c|c|c|c|c|c|}
\hline \multirow{3}{*}{ Variable } & \multicolumn{2}{|c|}{ CIPS test } & \multicolumn{4}{|l|}{ HK test } \\
\hline & \multirow[t]{2}{*}{ Level } & \multirow[t]{2}{*}{$\Delta$} & \multicolumn{2}{|l|}{ Level } & \multicolumn{2}{|l|}{$\Delta$} \\
\hline & & & $Z_{A}^{S P C}$ & $Z_{A}^{L A}$ & $Z_{A}^{S P C}$ & $Z_{A}^{L A}$ \\
\hline $\operatorname{lnCO} 2$ & -0.83 & $-6.48^{* * * *}$ & $13.74^{* * * *}$ & $15.71^{* * * *}$ & 0.44 & 1.05 \\
\hline $\ln G D P$ & -2.36 & $-4.35^{* * *}$ & $4.18^{* * * *}$ & $5.22^{* * * *}$ & 1.16 & $1.72^{* *}$ \\
\hline $\ln R E C$ & -1.78 & $-2.79^{* *}$ & $1.41^{*}$ & $1.78^{* *}$ & 1.03 & 1.16 \\
\hline
\end{tabular}


Table 5 Cointegration test results

\begin{tabular}{lll}
\hline Test & Constant & Constant and trend \\
\hline$D H_{\mathrm{g}}$ & $8.24^{* * * *}(0.00)$ & $11.56^{* * *}(0.00)$ \\
$D H_{\mathrm{p}}$ & $13.82^{* * * *}(0.00)$ & $14.66^{* * * *}(0.00)$ \\
\hline
\end{tabular}

$D H_{\mathrm{g}}$ and $D H_{\mathrm{p}}$ statistics are Durbin-Hausman group and panel statistics, respectively. The maximum number of factors is set to 3 . The bandwidth selection, Mi, corresponds to the largest integer less than $4(\mathrm{~T} / 100)^{2 / 9}$ as suggested by Newey and West (1994). $p$ values are reported in parentheses. ${ }^{* * *}$ The rejection of no cointegration null hypothesis at the $1 \%$ level of significance

macroeconomic variables from different cross sections; (ii) the estimators are robust to mixed stationary and nonstationary regressors; (iii) these estimators are consistent as they correct serial correlation and endogeneity.

The panel cointegration parameters are presented in Table 6. Both the CupBC and CupFM estimators yield similar results, and the estimated coefficients have a statistically significant impact on carbon emissions. We also performed dynamic seemingly unrelated cointegration regressions (DSUR) developed by Mark et al. (2005) to examine the concreteness of CupBC and CupFM estimations. The results of DSUR estimators were given in the fourth column of Table 6 . The similarity of the signs and magnitudes of the results between the CupBC/CupFM and DSUR estimators support the robustness of estimates. As the $t$ statistics of CupBC and CupFM estimators are greater than DSUR estimator, the CupBC and CupFM estimates are preferred over the AMG for interpretations.

The coefficients of GDP and its squared and cubed terms yield positive, negative, and positive estimators, respectively. As the resulting $p$ values are less than 5\%, which is the standard threshold for statistical significance, $\mathrm{N}$-shaped EKC in the Mediterranean countries forming the panel is confirmed. In this form of relationship, carbon emissions will increase

Table 6 Cointegration parameters

\begin{tabular}{llll}
\hline Variable & \multicolumn{2}{l}{ Dependent variable: $\mathrm{CO}_{2}$} \\
\cline { 2 - 4 } & CupBC & CupFM & DSUR \\
\hline $\ln G D P$ & $1.28^{* * * *}$ & $1.12^{* * * *}$ & $1.09^{* * * *}$ \\
& {$[9.55]$} & {$[10.23]$} & {$[5.18]$} \\
$\ln G D P^{2}$ & $-0.14^{* * * *}$ & $-0.12^{* * *}$ & $-0.09^{* * *}$ \\
& {$[-5.27]$} & {$[-4.81]$} & {$[-4.78]$} \\
$\ln G D P^{3}$ & $0.03^{* * * *}$ & $0.02^{* *}$ & $0.05^{*}$ \\
& {$[3.65]$} & {$[2.16]$} & {$[1.91]$} \\
$\ln R E C$ & $-0.12^{* * *}$ & $-0.17^{* * *}$ & $-0.21^{* * *}$ \\
& {$[-7.36]$} & {$[-6.51]$} & {$[-2.17]$} \\
\hline
\end{tabular}

\footnotetext{
${ }^{1}$ Values in brackets are $t$ statistics. ${ }^{* * *},{ }^{* *}$, and ${ }^{*}$ Significance at $1 \%, 5 \%$, and $10 \%$ levels, respectively
}

initially in line with income increases to the first turning point; then, emissions will decrease to the second turning point of income. Finally, emissions will start to increase again at the third turning point. Our finding of $\mathrm{N}$-shaped EKC is also supported by the studies of Sinha et al. (2017) for N-11 countries, Alvarez-Herranz et al. (2017) for 17 OECD countries, Barış-Tüzemen et al. (2020) for Turkey, Jiang et al. (2019) for 39 countries, Usama et al. (2020) for Ethiopia, among other studies.

As for the relationship between carbon emissions and renewable energy, our findings suggest that renewable energy is negatively linked to carbon emissions. In other words, holding all other variables constant, a $1 \%$ increase in renewable energy consumption will cause carbon emissions to decrease 0.12 $0.17 \%$. The economic interpretation of this result is that a transition to low-carbon economies cannot be achieved without renewable energy. This result supports the view of Magazzino et al. (2021b) that cutting carbon emissions cannot be achieved without conducting a comprehensive shift from fossil to renewable energy. This finding is also in line with the studies of Álvarez-Herránz et al. (2017) for 17 OECD countries, Sinha et al. (2017) for N-11 countries, BalsalobreLorente et al. (2018) for EU-5 countries, Zaidi et al. (2018) for Pakistan, among others.

\section{Conclusion and policy recommendations}

There is a broad consensus among the scientists that if GHGs keep growing at their current rate, the world will see irreversible climate change (Huntingford et al. 2012; Oberheitmann 2013; Friedlingstein et al. 2014; Le Kama et al. 2014, among others). Among the GHGs, energy-related carbon emissions account for two-thirds of all emissions.

Mediterranean countries are mostly energy-dependent. Also, the countries in the region have been facing high demographic growth and rapid urbanization. On the other hand, the Mediterranean region is endowed with massive renewable energy sources owing to its climate, geography, and geological features. The region has high levels of solar radiation one of the world's greatest - and exceptional wind conditions. However, solar and wind energy represent only around $1 \%$ of the region's electricity generation mix. In addition, the share of renewable energy in the Mediterranean region energy mix accounts for approximately $17 \%$. Therefore, the main goal in establishing the energy policies should be turning to renewable energy resources, as the Mediterranean region has remarkable potential to turn into a renewable energy hub.

Renewable energy stands out as an important solution to global warming and other environmental issues. This paper aimed to analyze whether renewable energy can be used in the decarbonization of the Mediterranean region through the $\mathrm{N}$ shaped EKC hypothesis. To reach this purpose, we 
investigated the relationship between carbon emissions, income, and renewable energy consumption in 17 Mediterranean countries over the period 1990-2017. We started panel time series analysis by examining the crosssectional dependency. Proceeding with second-generation panel unit root tests of Pesaran (2007) and Hadri and Kurozumi (2012), we found that all the variables are stationary at their first differences. The results of Westerlund's (2008) test showed that there is a long-run relationship among the variables. We obtained the long-term coefficients using CupBC and CupFM estimators and performed a robustness check through DSUR estimator. The signs of per capita GDP, GDP squared, and GDP cubed indicate that a cubic polynomial N-shaped relationship between per capita income and carbon dioxide emissions exists in the case of Mediterranean countries. In addition, the elasticity of carbon emissions with respect to renewable energy consumption is found to be -0.12 and -0.17 for CupBC and CupFM estimators, respectively.

There are important policy implications to be drawn from our results. Mediterranean countries should follow concrete strategies to combat the adverse effects of environmental degradation. Firstly, the countries should set down stronger energy efficiency requirements. As income is a major determinant of carbon emissions, countries should devise new ways to produce the same or even more output by using less energy. In its report, IEA estimates that two-thirds of the global economic potential of energy efficiency remains untapped. With energy-efficient production, carbon emissions could be controlled without compromising economic growth. Subsidies could be used for critical industries to cut carbon emissions. Also, carbon taxes could be levied by governments on carbonintensive industries. As for renewable energy, both alternative energy sources such as solar, wind, geothermal, and environment-friendly technologies could be supported.

In addition, a region-wide initiative should be launched to collaboratively plan and implement a transition to renewable energy in the Mediterranean region. The exploitation of the untapped renewable energy potential will provide many benefits to the region. The countries in the region will satisfy their energy demand with a lower cost and decrease their energy import bill. It will also provide price stability as the renewable energy sources do not involve fuel cost or require transportation which are the main reasons for price fluctuations in the market for conventional energy sources. On the employment side, as Magazzino et al. (2021a) state, the adoption of renewable energy can also provide job opportunities and stimulate the growth of industries. On the policy side, the governments should pave the way for renewables by removing the financial, regulatory, and technological barriers. Therefore, the use of renewables can grow fast with the expansion of wind and solar technologies.

Using alternative energy sources will contribute to making renewable energy claim a bigger share in production which in turn will decrease carbon emissions. The finance sector can also be used as a tool to create incentives for industries that adopt cleaner and environment-friendly technologies. In line with this policy recommendation, Köksal et al. (2021) recently showed that financial markets and institutions stimulate renewable energy demand. Last but not least, the governments of Mediterranean countries should prepare an aggressive plan and timeframe for decarbonization.

Finally, it is also worth noting that even though countries may object to being equally responsible for global warming and climate change, all the countries should arrive at a consensus to address this threat collaboratively since no country can avert it alone.

\section{Future research}

This study contributes to the ongoing discussion on the EKC model in a cubic form for the case of Mediterranean countries. Future studies may analyze the country-specific results in order to provide country-based policy recommendations. Further research could also consider incorporating additional variables such as urbanization and trade openness which also pose a risk to the environment. There is also the need to include a more recent dataset to capture the profound effects of the Covid-19 on the economies.

Acknowledgements We would like to express our utmost gratitude to the editor and three anonymous reviewers for their valuable suggestions and comments, which significantly improved this paper. We also thank Goktug Yucel of Erciyes University for carefully proofreading the manuscript. Any remaining errors are our own responsibility.

Availability of data and materials The datasets used and/or analyzed during the current study are available from the corresponding author on reasonable request.

Author contribution ZSU: conceptualization, methodology, formal analysis, software, supervision, writing — review and editing. AGY: resources, data curation, writing - original draft, writing — review and editing. Both authors read and approved the final manuscript.

\section{Declarations}

Ethics approval and consent to participate Not applicable.

Consent for publication Not applicable.

Competing interests The authors declare no competing interests.

\section{References}

Akram R, Chen F, Khalid F, Ye Z, Majeed MT (2020) Heterogeneous effects of energy efficiency and renewable energy on carbon 
emissions: evidence from developing countries. J Clean Prod 247: 119122. https://doi.org/10.1016/j.jclepro.2019.119122

Aldy JE (2006) Per capita carbon dioxide emissions: convergence or divergence? Environ Resour Econ 33:533-555. https://doi.org/10. 1007/s10640-005-6160-x

Alola AA, Yalçiner K, Alola UV (2019) Renewables, food (in)security, and inflation regimes in the coastline Mediterranean countries (CMCs): the environmental pros and cons. Environ Sci Pollut Res 26:34448-34458. https://doi.org/10.1007/s11356-019-06576-y

Alvarez-Herranz A, Balsalobre-Lorente D, Shahbaz M, Cantos JM (2017) Energy innovation and renewable energy consumption in the correction of air pollution levels. Energy Policy 105:386-397. https://doi.org/10.1016/j.enpol.2017.03.009

Baek J (2016) Do nuclear and renewable energy improve the environment? Empirical evidence from the United States. Ecol Indic 66: 352-356. https://doi.org/10.1016/j.ecolind.2016.01.059

Bai J, Kao C, Ng S (2009) Panel cointegration with global stochastic trends. J Econ 149:82-99. https://doi.org/10.1016/J.JECONOM. 2008.10.012

Balado-Naves R, Baños-Pino JF, Mayor M (2018) Do countries influence neighbouring pollution? A spatial analysis of the EKC for $\mathrm{CO} 2$ emissions. Energy Policy 123:266-279. https://doi.org/10.1016/j. enpol.2018.08.059

Baležentis T, Streimikiene D, Zhang T, Liobikiene G (2019) The role of bioenergy in greenhouse gas emission reduction in EU countries: an environmental Kuznets curve modelling. Resour Conserv Recycl 142:225-231. https://doi.org/10.1016/j.resconrec.2018.12.019

Balsalobre-lorente D, Shahbaz M, Roubaud D, Farhani S (2018) How economic growth, renewable electricity and natural resources contribute to CO2emissions? Energy Policy 113:356-367. https://doi. org/10.1016/j.enpol.2017.10.050

Barış-Tüzemen Ö, Tüzemen S, Çelik AK (2020) Does an N-shaped association exist between pollution and ICT in Turkey? ARDL and quantile regression approaches. Environ Sci Pollut Res 27:2078620799. https://doi.org/10.1007/s11356-020-08513-w

Bekhet HA, Othman NS (2018) The role of renewable energy to validate dynamic interaction between CO2 emissions and GDP toward sustainable development in Malaysia. Energy Econ 72:47-61. https:// doi.org/10.1016/j.eneco.2018.03.028

Bhattacharya M, Awaworyi Churchill S, Paramati SR (2017) The dynamic impact of renewable energy and institutions on economic output and CO2 emissions across regions. Renew Energy 111:157-167. https://doi.org/10.1016/J.RENENE.2017.03.102

Bilgili F, Ulucak R (2018) Is there deterministic, stochastic, and/or club convergence in ecological footprint indicator among G20 countries? Environ Sci Pollut Res 25:35404-35419. https://doi.org/10.1007/ s11356-018-3457-1

Bilgili F, Koçak E, Bulut Ü (2016) The dynamic impact of renewable energy consumption on $\mathrm{CO} 2$ emissions: a revisited environmental Kuznets curve approach. Renew Sust Energ Rev 54:838-845. https://doi.org/10.1016/J.RSER.2015

Bilgili F, Ulucak R, Koçak E (2019) Implications of environmental convergence: continental evidence based on ecological footprint. In: Shahbaz M, Balsalobre D (eds). Springer, pp 133-165

Bölük G, Mert M (2015) The renewable energy, growth and environmental Kuznets curve in Turkey: an ARDL approach. Renew Sust Energ Rev 52:587-595. https://doi.org/10.1016/J.RSER.2015.07.138

Breusch TS, Pagan AR (1980) The Lagrange multiplier test and its applications to model specification in econometrics. Rev Econ Stud 47:239. https://doi.org/10.2307/2297111

Carrion-i-Silvestre JL, Del Barrio-Castro T, López-Bazo E (2005) Breaking the panels: an application to the GDP per capita. Econ J 8:159-175. https://doi.org/10.1111/j.1368-423X.2005.00158.x

Cetin M, Ecevit E, Yucel AG (2018) Structural breaks, urbanization and $\mathrm{CO} 2$ emissions: evidence from Turkey. J Appl Econ Bus Res 8: $122-139$
Chen Y, Wang Z, Zhong Z (2019) CO2 emissions, economic growth, renewable and non-renewable energy production and foreign trade in China. Renew Energy 131:208-216. https://doi.org/10.1016/j. renene.2018.07.047

Choi I (1993) Asymptotic normality of the least-squares estimates for higher order autoregressive integrated processes with some applications. Economic Theory 9:263-282. https://doi.org/10.1017/ S0266466600007532

Christensen JH, Kumar KK, Aldrian E et al (2013) Climate phenomena and their relevance for future regional climate change. In: Stocker TF, Qin D, Plattner G-K et al (eds) Climate Change 2013: The Physical Science Basis. Contribution of Working Group I to the Fifth Assessment Report of the Intergovernmental Panel on Climate Change. Cambridge University Press, Cambridge, United Kingdom, pp 1217-1308

Cook BI, Anchukaitis KJ, Touchan R, Meko DM, Cook ER (2016) Spatiotemporal drought variability in the Mediterranean over the last 900 years. J Geophys Res Atmos 121:2060-2074. https://doi.org/ 10.1002/2015JD023929

Danish ZB, Wang B, Wang Z (2017) Role of renewable energy and nonrenewable energy consumption on EKC: evidence from Pakistan. J Clean Prod 156:855-864. https://doi.org/10.1016/j.jclepro.2017.03. 203

Destek MA, Ulucak R, Dogan E (2018) Analyzing the environmental Kuznets curve for the EU countries: the role of ecological footprint. Environ Sci Pollut Res 25:29387-29396. https://doi.org/10.1007/ s11356-018-2911-4

Dinda S (2004) Environmental Kuznets Curve hypothesis: a survey. Ecol Econ 49:431-455. https://doi.org/10.1016/j.ecolecon.2004.02.011

Dong K, Sun R, Jiang H, Zeng X (2018) CO2 emissions, economic growth, and the environmental Kuznets curve in China: what roles can nuclear energy and renewable energy play? J Clean Prod 196: 51-63. https://doi.org/10.1016/J.JCLEPRO.2018.05.271

Erdogan S, Okumus I, Guzel AE (2020) Revisiting the environmental Kuznets curve hypothesis in OECD countries: the role of renewable, non-renewable energy, and oil prices. Environ Sci Pollut Res 27: 23655-23663. https://doi.org/10.1007/s11356-020-08520-x

Erdoğan S, Yıldırım S, Yıldırım DÇ, Gedikli A (2020) The effects of innovation on sectoral carbon emissions: evidence from G20 countries. J Environ Manag 267:110637. https://doi.org/10.1016/j. jenvman.2020.110637

Friedlingstein P, Andrew RM, Rogelj J, Peters GP, Canadell JG, Knutti R, Luderer G, Raupach MR, Schaeffer M, van Vuuren DP, le Quéré C (2014) Persistent growth of CO2 emissions and implications for reaching climate targets. Nat Geosci 7:709-715. https://doi.org/10. 1038/ngeo2248

Frölicher TL, Laufkötter C (2018) Emerging risks from marine heat waves. Nat Commun 9:1-4

Grossman GM, Krueger AB (1991) Environmental impacts of a North American free trade agreement. Natl Bur Econ Res Work Pap Ser No 3914:1-57. https://doi.org/10.3386/w3914

Grossman GM, Krueger AB (1995) Economic growth and the environment. Q J Econ 110:353-377. https://doi.org/10.2307/2118443

Guiot J, Cramer W (2016) Climate change: the 2015 Paris Agreement thresholds and Mediterranean basin ecosystems. Science 354(80): 465-468. https://doi.org/10.1126/science.aah5015

Gürlük S (2009) Economic growth, industrial pollution and human development in the Mediterranean Region. Ecol Econ 68:2327-2335. https://doi.org/10.1016/j.ecolecon.2009.03.001

Hadri K, Kurozumi E (2012) A simple panel stationarity test in the presence of serial correlation and a common factor. Econ Lett 115:3134. https://doi.org/10.1016/J.ECONLET.2011.11.036

Hassan ST, Xia E, Lee C-C (2021) Mitigation pathways impact of climate change and improving sustainable development: the roles of natural resources, income, and CO 2 emission. Energy Environ 32:338 363. https://doi.org/10.1177/0958305X20932550 
Herrerias MJ (2013) The environmental convergence hypothesis: carbon dioxide emissions according to the source of energy. Energy Policy 61:1140-1150. https://doi.org/10.1016/j.enpol.2013.06.120

Hsiao C (2014) Analysis of panel data, 3rd edn. Cambridge University Press, New York, NY

Huntingford C, Lowe JA, Gohar LK, Bowerman NHA, Allen MR, Raper SCB, Smith SM (2012) The link between a global $2{ }^{\circ} \mathrm{C}$ warming threshold and emissions in years 2020, 2050 and beyond. Environ Res Lett 7:014039. https://doi.org/10.1088/1748-9326/7/1/014039

Inglesi-Lotz R, Dogan E (2018) The role of renewable versus nonrenewable energy to the level of $\mathrm{CO} 2$ emissions a panel analysis of sub-Saharan Africa's Big 10 electricity generators. Renew Energy 123:36-43. https://doi.org/10.1016/j.renene.2018.02.041

IPCC (2014) Climate change 2014: synthesis report. Contribution of Working Groups I, II and III to the Fifth Assessment Report of the Intergovernmental Panel on Climate Change

IPCC (2018) Global warming of $1.5^{\circ} \mathrm{C}$ : an IPCC special report on the impacts of global warming of $1.5^{\circ} \mathrm{C}$ above pre-industrial levels and related global greenhouse gas emission pathways, in the context of strengthening the global response to the threat of climate change. Geneva, Switzerland

Jebli MB, Youssef SB (2015) The environmental Kuznets curve, economic growth, renewable and non-renewable energy, and trade in Tunisia. Renew Sust Energ Rev 47:173-185. https://doi.org/10. 1016/j.rser.2015.02.049

Jiang L, He S, Zhong Z, Zhou H, He L (2019) Revisiting environmental Kuznets curve for carbon dioxide emissions: the role of trade. Struct Chang Econ Dyn 50:245-257. https://doi.org/10.1016/j.strueco. 2019.07.004

Kim GU, Seo KH, Chen D (2019) Climate change over the Mediterranean and current destruction of marine ecosystem. Nature-Scientific Reports 9:1-9. https://doi.org/10.1038/s41598019-55303-7

Köksal C, Ișik M, Katircioglu S (2020) The role of shadow economies in ecological footprint quality: empirical evidence from Turkey. Environ Sci Pollut Res 27:13457-13466. https://doi.org/10.1007/ s11356-020-07956-5

Köksal C, Setareh K, Salih K (2021) The role of financial efficiency in renewable energy demand: evidence from OECD countries. J Environ Manag 285:112122. https://doi.org/10.1016/j.jenvman. 2021.112122

Kuznets S (1955) Economic growth and income inequality. Am Econ Rev 45:1-28. https://doi.org/10.2307/2118443

Le Kama AA, Pommeret A, Prieur F (2014) Optimal emission policy under the risk of irreversible pollution. J Public Econ Theory 16: 959-980. https://doi.org/10.1111/jpet.12085

Liu X, Zhang S, Bae J (2017) The impact of renewable energy and agriculture on carbon dioxide emissions: investigating the environmental Kuznets curve in four selected ASEAN countries. J Clean Prod 164:1239-1247. https://doi.org/10.1016/J.JCLEPRO.2017.07. 086

López-Menéndez AJ, Pérez R, Moreno B (2014) Environmental costs and renewable energy: re-visiting the environmental Kuznets curve. J Environ Manag 145:368-373. https://doi.org/10.1016/j.jenvman. 2014.07.017

Magazzino C (2017) Renewable energy consumption-economic growth nexus in Italy. Int J Energy Econ Policy 7:119-127

Magazzino C, Mele M, Morelli G (2021a) The relationship between renewable energy and economic growth in a time of Covid-19: a machine learning experiment on the Brazilian economy. Sustainability 13:1285. https://doi.org/10.3390/su13031285

Magazzino C, Mele M, Schneider N (2021b) A machine learning approach on the relationship among solar and wind energy production, coal consumption, GDP, and CO2 emissions. Renew Energy 167: 99-115. https://doi.org/10.1016/j.renene.2020.11.050
Mahmood N, Wang Z, Hassan ST (2019) Renewable energy, economic growth, human capital, and $\mathrm{CO} 2$ emission: an empirical analysis. Environ Sci Pollut Res 26:20619-20630. https://doi.org/10.1007/ s11356-019-05387-5

Mark NC, Ogaki M, Sul D (2005) Dynamic seemingly unrelated cointegrating regressions. Rev Econ Stud 72:797-820. https://doi. org/10.1111/j.1467-937X.2005.00352.x

Mathbout S, Lopez-Bustins JA, Royé D, Martin-Vide J, Benhamrouche A (2020) Spatiotemporal variability of daily precipitation concentration and its relationship to teleconnection patterns over the Mediterranean during 1975-2015. Int J Climatol 40:1435-1455. https://doi.org/10.1002/joc.6278

Menegaki AN, Tsagarakis KP (2015) Rich enough to go renewable, but too early to leave fossil energy? Renew Sust Energ Rev 41:14651477. https://doi.org/10.1016/j.rser.2014.09.038

Najam A, Huq S, Sokona Y (2003) Climate negotiations beyond Kyoto: developing countries concerns and interests. Clim Pol 3:221-231. https://doi.org/10.3763/cpol.2003.0329

Nashwan MS, Shahid S, Chung E-S (2020) High-resolution climate projections for a densely populated Mediterranean region. Sustainability 12:3684. https://doi.org/10.3390/su12093684

Oberheitmann A (2013) Some remarks on the individual contribution to climate change. Am J Clim Chang 02:198-202. https://doi.org/10. 4236/ajcc.2013.23020

Öztürk I, Özcan B (eds) (2019) Environmental Kuznets curve (EKC). Elsevier

Panayotou T (1993) Empirical tests and policy analysis of environmental degradation at different stages of economic development. Geneva

Panayotou T (1995) Environmental degradation at different stages of economic development. ILO Studies series, New York, NY

Pao HT, Chen CC (2019) Decoupling strategies: CO2 emissions, energy resources, and economic growth in the Group of Twenty. J Clean Prod 206:907-919. https://doi.org/10.1016/j.jclepro.2018.09.190

Pesaran MH (2007) A simple panel unit root test in the presence of crosssection dependence. J Appl Econ 22:265-312. https://doi.org/10. $1002 /$ jae. 951

Pesaran MH, Ullah A, Yamagata T (2008) A bias-adjusted LM test of error cross-section independence. The Econometrics Journal 11(1): $105-127$

Pincheira R, Zuniga F (2020) Environmental Kuznets curve bibliographic map: a systematic literature review. Account Finance 61:19311956. https://doi.org/10.1111/acfi.12648

Puaschunder J (2020) Global climate justice. In: Governance \& climate justice. Palgrave Macmillan, pp 39-81

Rosen AM (2015) The wrong solution at the right time: the failure of the Kyoto Protocol on climate change. Polit Policy 43:30-58. https:// doi.org/10.1111/polp.12105

Sarkodie SA, Ozturk I (2020) Investigating the environmental Kuznets curve hypothesis in Kenya: a multivariate analysis. Renew Sust Energ Rev 117:109481. https://doi.org/10.1016/j.rser.2019.109481

Shafik N (1994) Economic development and environmental quality: an econometric analysis. Oxf Econ Pap 46:757-773

Shahbaz M, Lean HH, Shabbir MS (2012) Environmental Kuznets curve hypothesis in Pakistan: cointegration and Granger causality. Renew Sust Energ Rev 16:2947-2953. https://doi.org/10.1016/j.rser.2012. 02.015

Sharif A, Raza SA, Ozturk I, Afshan S (2019) The dynamic relationship of renewable and nonrenewable energy consumption with carbon emission: a global study with the application of heterogeneous panel estimations. Renew Energy 133:685-691. https://doi.org/10.1016/j. renene.2018.10.052

Sinha A, Shahbaz M (2018) Estimation of environmental Kuznets curve for $\mathrm{CO} 2$ emission: role of renewable energy generation in India. Renew Energy 119:703-711. https://doi.org/10.1016/j.renene. 2017.12.058 
Sinha A, Shahbaz M, Balsalobre D (2017) Exploring the relationship between energy usage segregation and environmental degradation in N-11 countries. J Clean Prod 168:1217-1229. https://doi.org/10. 1016/j.jclepro.2017.09.071

Stern DI (2017) The environmental Kuznets curve after 25 years. J Bioecon 19:7-28. https://doi.org/10.1007/s10818-017-9243-1

Sugiawan Y, Managi S (2016) The environmental Kuznets curve in Indonesia: exploring the potential of renewable energy. Energy Policy 98:187-198. https://doi.org/10.1016/j.enpol.2016.08.029

Sul D, Phillips PCB, Choi C-Y (2005) Prewhitening bias in HAC estimation. Oxf Bull Econ Stat 67:517-546. https://doi.org/10.1111/j. 1468-0084.2005.00130.x

Toda HY, Yamamoto T (1995) Statistical inference in vector autoregressions with possibly integrated processes. J Econ 66: 225-250. https://doi.org/10.1016/0304-4076(94)01616-8

Ulucak R, Yücel AG, Koçak E (2019) The process of sustainability: from past to present. In: Özcan B, Öztürk İ (eds) Environmental Kuznets curve (EKC): a manual. Elsevier, pp 37-53

Ulucak R, Kassouri Y, İlkay SÇ et al (2020a) Does convergence contribute to reshaping sustainable development policies? Insights from Sub-Saharan Africa. Ecol Indic 112:106140. https://doi.org/10. 1016/j.ecolind.2020.106140

Ulucak R, Yücel AG, İlkay SÇ (2020b) Dynamics of tourism demand in Turkey: panel data analysis using gravity model. Tour Econ 26: 1394-1414. https://doi.org/10.1177/1354816620901956

Usama AM, Solarin SA, Salahuddin M (2020) The prominence of renewable and non-renewable electricity generation on the environmental Kuznets curve: a case study of Ethiopia. Energy 211:118665. https:// doi.org/10.1016/j.energy.2020.118665

Vehmas J, Luukkanen J, Kaivo-oja J (2007) Linking analyses and environmental Kuznets curves for aggregated material flows in the EU. J Clean Prod 15:1662-1673. https://doi.org/10.1016/j.jclepro.2006. 08.010

Westerlund J, Basher SA (2008) Testing for convergence in carbon dioxide emissions using a century of panel data. Environ Resour Econ 40:109-120. https://doi.org/10.1007/s10640-007-9143-2
Westerlund J, Hosseinkouchack M (2016) Modified CADF and CIPS panel unit root statistics with standard chi-squared and normal limiting distributions. Oxf Bull Econ Stat 78:347-364. https://doi.org/ 10.1111/obes. 12127

Yao S, Zhang S, Zhang X (2019) Renewable energy, carbon emission and economic growth: a revised environmental Kuznets curve perspective. J Clean Prod 235:1338-1352. https://doi.org/10.1016/j. jclepro.2019.07.069

Yilanci V, Ozgur O (2019) Testing the environmental Kuznets curve for G7 countries: evidence from a bootstrap panel causality test in rolling windows. Environ Sci Pollut Res 26:24795-24805. https:// doi.org/10.1007/s11356-019-05745-3

Yucel AG (2020) Are shocks to tourist arrivals permanent or transitory? A comprehensive analysis on the top 20 most-visited countries. Curr Issues Tour 1-18. https://doi.org/10.1080/13683500.2020.1828311

Zafeiriou E, Azam M (2017) CO2 emissions and economic performance in EU agriculture: some evidence from Mediterranean countries. Ecol Indic 81:104-114. https://doi.org/10.1016/j.ecolind.2017.05. 039

Zaidi SAH, Danish HF, Mirza FM (2018) The role of renewable and nonrenewable energy consumption in $\mathrm{CO} 2$ emissions: a disaggregate analysis of Pakistan. Environ Sci Pollut Res 25:31616-31629. https://doi.org/10.1007/s11356-018-3059-y

Zambrano-Monserrate MA, Silva-Zambrano CA, Davalos-Penafiel JL, Zambrano-Monserrate A, Ruano MA (2018) Testing environmental Kuznets curve hypothesis in Peru: the role of renewable electricity, petroleum and dry natural gas. Renew Sust Energ Rev 82:4170 4178

Zoundi Z (2017) CO2 emissions, renewable energy and the environmental Kuznets curve, a panel cointegration approach. Renew Sust Energ Rev 72:1067-1075. https://doi.org/10.1016/J.RSER.2016. 10.018

Publisher's note Springer Nature remains neutral with regard to jurisdictional claims in published maps and institutional affiliations. 